\title{
Challenges in Sri Lankan Heritage Management with the Covid 19 Pandemic
}

\author{
Gunasekara, I'., Rathnayaka, $\mathbf{J}^{2}$ \\ ${ }^{1}$ Lecturer, University of Vocational Technology, Ratmalana, Sri Lanka \\ ${ }^{2}$ Lecturer, University College of Ratmalana, Ratmalana, Sri Lanka \\ 1.indrachapa@uovt.ac.lk
}

\begin{abstract}
Heritage Management is a field which has been developed to conserve, preserve and manage the cultural heritage of any country for promoting it to the visitors. Heritage management also incurred with marketing, visitor management and community empowerment. Due to the Covid 19 Pandemic, this respected field has been very much impacted and forced to face an economic downfall. This research has attempted to identify the major problems faced by heritage managers in the safety of the staff, visitor management, and maintaining heritage. The recommendations are made in three challenging fields and, also sustainable best practices are suggested at the end for the long run in a pandemic Covid 19. The study is primarily based on mix method while using both primary and secondary data such as library material, journals and reports, media publications and various internet search engines. Convenient sampling has been used to select the sample for the questionnaire survey. As per the empirical studies, it was revealed that proper usage of guidelines and good practices for the management of the heritages incorporating the high technology in a sustainable manner may support to be endured during the pandemic.
\end{abstract}

Keywords: Heritage management, covid 19, pandemic, challenges and visitor management 


\section{Introduction}

Heritage management plays a very important role in the protection and conservation of the cultural heritage of any country. There are numerous studies that identified in heritage management field. Heritage Management faces different challenges affected by both micro and macro-environmental changes. A pandemic situation is counted as a macro environment modification that has affected almost every industry and field. Consequently, this study has been focused on the impacts of Covid 19 on heritage management in Sri Lanka.

\section{Research Aim}

Heritage Management in Sri Lanka has been experiencing numerous difficulties post-Covid 19 pandemic. The focus of this study is to evaluate the problems faced in heritage management by the Sri Lankan government's authorities due to Covid 19 pandemic.

\section{Objectives}

To evaluate the major challenges and recommend good practices for heritage management in Sri Lanka after Covid 19.

To define functions of heritage management

To identify the challenges faced by heritage managers in Sri Lanka after Covid 19

To suggest solutions for the challenges

To recommend good practices for the function of heritage sites in the pandemic situation

\section{Significance of the Study}

Cultural heritage of Sri Lanka plays a vital role in the development of the tourism industry. With the arise of Covid 19 pandemic, the Sri Lankan tourism industry falls to zero number of tourists' arrival from overseas. Every business that has been relied on tourism faced a drastic economic downfall. The heritage sites that were managed by the tourist donations and entrance fees are also experiencing a massive 
depression due to a lack of funds for maintenance. This study is attempted to indepth identification of problems faced by heritage managers and suggests sustainable practices for the survival of tourism associated with the cultural heritage of the country post-Covid 19 pandemic.

\section{Materials and Methods}

Research Tools and the Sample

The study utilized both primary and secondary data. A desktop survey was carried out for the collection of secondary data. The questionnaire was used as a tool for the collection of primary data. The questionnaire has been distributed among hundred and twenty (120) heritage management staff (The employees in middle management and supervisory category) in different heritage sites as a google form. The response rate of the questionnaire is $56 \%$ which is above the least percentage of research acceptances.

\section{Limitations of the Study}

There are two major types when it comes to heritage, natural heritage and cultural heritage. This study solely focused on cultural heritage sites due to a lack of research resources. There are eight World Heritage Sites in Sri Lanka. Out of them, six were recorded as cultural heritage sites. Besides, there are many cultural heritage sites that are recorded under the Archaeology Department and Central Cultural Fund. This study is carried out based on seven (07) cultural heritage sites. Those sites are; Anuradhapura Abhayagiriya site and Museum, Sigiriya Heritage Site, Galle Maritime Museum, Jaffna Fort, Fredrick Fort Trincomalee, Colombo National Museum and Kandy Archaeology Museum. 


\section{Results and Discussion}

\section{Covid 19}

Covid 19 or Corona is a pandemic that arise during the end of the year 2019 and continues throughout 2020 and is predicted to be positive for another two or three years as of the World Health Organization. This pandemic is an influenza virus that is spread by the touch and air. Almost all the countries in the world are suffering from Covid 19 pandemic, up to date the number of cases is 219 million and counting. This pandemic severely damaged almost all industries including agriculture, manufacturing, travel and tourism, and airlines. Each person and every business is directly or indirectly influenced by the pandemic causing terminations and shifting to new businesses. When it comes to welfare and wellbeing, there were huge amounts of money from the governments have to be pumped to the health and safety of the public. This results in less focus on conservation and preservation work in cultural and natural heritage. At a glance, it seems fair enough to cut the funds for such projects since most of the citizens even lost their jobs and some companies had to entertain the salary reductions. With such a huge economic downfall it is acceptable to face some difficulties in any field.

\section{Heritage}

Heritage is something associated with illustrious cultural or nature's aspects and that has to be preserved and pass to the next generations. Heritage is defined in numerous means. The Quebec Association for the Interpretation of National Heritage in 1980 has defined heritage as "the combined creations and products of nature and man, in their entirety that make up the environment in which we live in space and time. Heritage is a reality, a possession of the community, and a rich inheritance that may be passed on, which invites our recognition and our participation" (Richards 2018). According to UNESCO, heritage could be categorized in two as cultural heritage and natural heritage. Cultural heritage is incurred with tangible and intangible aspects of heritage. Tangible heritage means the movable, immovable, or underwater heritage such as paintings, sculptures, 
monuments, shipwrecks, and archaeological sites. Under intangible heritage, the traditions, performing arts, rituals, and folklore could be categorized. However, the cultural heritage is founded, developed, and shaped by humans and society (Petronela 2016). Natural Heritage is the heritage that is formed by nature, likewise landscapes, biological and geological formations (Hua 2010).

Heritage Management

Heritage Management is a recently popularized subject area that has been generated with the heritage protection practices since ancient times. Though the terminology is quite new, the concept and the scope were bounded with the heritage. The field of Heritage Management is constructed with the identification, protection, and care of cultural heritage. It is a purely developed subject for the care of heritage and maintenance of heritage sites. Excavations, documentation of findings, conservation, research, education and marketing of heritage are key areas of heritage management (Heritage et al. 2018; Marmion, Calver, and Wilkes 2010). Heritage Management is more often connected to heritage economics and revenue management. There is no use of heritage management if it does not consider revenue generation. The revenue generated at the heritage sites are directly going to site maintenance and employee salaries. Heritage Management is now being integrated with the tourism industry. Heritage management balances the development of the tourism industry and the integrity of the site. As a result, many tourism concepts have been formed related to heritage. Cultural Tourism, Archaeological Tourism, Heritage Tourism, Maritime Archaeological Tourism, Intangible Tourism are some of such respective concepts designed with heritage management (Buckley 2014; Richards 2013). In the development of heritage management, there are a few areas to be considered by the Heritage Management Professionals such as working with Local Communities, Educating and Empowering Visitors, Visitor Management, and Cultural Heritage Marketing. Heritage Managers must consider the local communities when planning visitor activities at the site. There should be an approach to create opportunities for local businesses around the heritage site. It should be a long-term sustainable 
development plan (Li 2000). Restaurants, shops, taxi services, hotels, rest houses are some of the key areas that the local communities gain economic benefits.

Visitor Education and Empowerment play a vital role in the management of heritage. The visitors also have a huge responsibility towards heritage protection and preservation. To encourage and guide them to do so, heritage managers must empower them with information, guidelines, and necessary tools (Gunasekara 2019). Nowadays, self-guiding mobile applications, awareness programs, site interpretations are used to educate visitors. Mostly visitor centred learning activities are promoted at the heritage sites (Walker 2008). As a result of visitor inflow in the sites, it is needed to manage those visitors properly to establish the sustainable operation of a heritage site. The heritage managers should have a proper understanding of the carrying capacity of the heritage site when planning visitor management (Singer 2012). Visitor management is a subject that manages to attract visitors without risking physical damage to the site. Management of visitor flow, limiting access, visitation time allocation, visitor welfare, visitor activities, visitor information management are some of the key functionalities of visitor management. Another principal role of a heritage manager is heritage marketing. The tourism industry displays enormous competition to attract visitors. Therefore, heritage managers involve in site marketing in attracting visitors to the site and to raise awareness about the site. These managers involve in destination branding, place branding and individual attraction branding in order to keep the clientele attracted (Thorell 2018).

\section{Analysis of Findings}

The major finding of the questionnaire survey is mentioned in this section.

\section{Heritage Management Practices}

The sources of income of the heritage sites are recorded to be the entrance fees of the visitors. As of figure 1 , it is indicated that $82 \%$ of the respondents selected Entrance fees as the source of income. Also, $18 \%$ mentioned that it is the government funds, which means the reduction of the number of visitation to the 
sites decreases the income generation. Since the travel limitations are delayed and the tourist arrivals are limited the major sources of income of these heritage sites are impacted as a drawback effect.

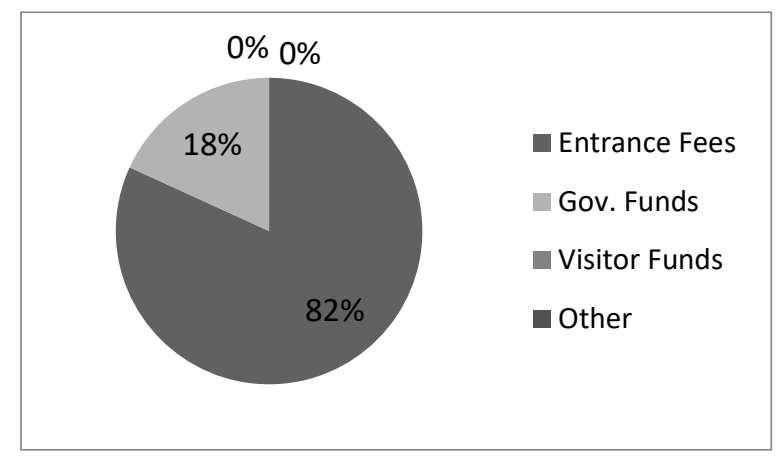

Figure 1: Major Sources of Income

After the lockdown, the heritage sites were reopened with the usual functions for domestic tourists. All the respondents stated that the health precautions were introduced to the heritage managers when reopening the sites. The visitor management staff was also empowered by the health practices. The international visitations remain zero due to the flight limitations and the health guidelines for foreigners. The site promotes domestic visitors with the following safety precautions.

Temperature check

Handwashing facilities

Tourists are not allowed to enter the site without masks

Limit the number of tourists entering the site

Discourage group travellers

\begin{tabular}{|l|l|}
\hline $\begin{array}{l}\text { Challenges faced by } \\
\text { heritage managers } \\
\text { after Covid 19 }\end{array}$ & $\begin{array}{l}\text { The challenges faced by heritage managers and staff in } \\
\text { managing visitors, following self-safety measures and site } \\
\text { protection are mentioned in this section. }\end{array}$ \\
\hline Challenges face by & Employees are not provided with the proper instructions \\
\hline
\end{tabular}




\begin{tabular}{|c|c|}
\hline staff & $\begin{array}{l}\text { Employees are not empowered with the personal safety } \\
\text { equipment } \\
\text { Negligence of the visitors on precaution measures } \\
\text { Education officers and guides are having direct contact } \\
\text { with the visitors for more than } 30 \text { mins causing too much } \\
\text { exposure to outsiders } \\
\text { Fewer hygiene facilities at the sites } \\
\text { The temporary and contract staff members lose their jobs } \\
\text { due to less income }\end{array}$ \\
\hline $\begin{array}{l}\text { Challenges of } \\
\text { Managing Visitors }\end{array}$ & $\begin{array}{l}\text { Some visitors do not follow the instructions causing other } \\
\text { visitors and staff in danger } \\
\text { Domestic visitors travel in groups, resulting in difficulties } \\
\text { to manage the space and social distance at the site } \\
\text { Inability to focus on visitor education and welfare with the } \\
\text { safety practices }\end{array}$ \\
\hline $\begin{array}{l}\text { Challenges of Site } \\
\text { safety }\end{array}$ & $\begin{array}{l}\text { There is an enormous trend in domestic group travel after } \\
\text { the lockdown. It causes to the damage site due to } \\
\text { exceeding carrying capacity. } \\
\text { Lack of consciousness of the tourists about the importance } \\
\text { of artefacts (sitting on stone artefacts, walking on stone } \\
\text { columns and writing names on trees and stones) }\end{array}$ \\
\hline
\end{tabular}

Table 1: Challenges faced in Heritage Management

\section{Best Practices for the Function of Heritage Sites in Pandemic Situation}

Best practices are a set of guidelines, ethics, or ideas that represent the most efficient or prudent course of action, in a given business situation. Best practices may be established by authorities, such as regulators or governing bodies, or they may be internally decreed by a company's management team. A best practice is a method or a technique that has been generally accepted as superior to any alternatives because it produces results that are superior to those achieved by other means or because it has become a standard way of doing things, e.g., a standard way 
of complying with legal or ethical requirements. Best practices are used to maintain quality as an alternative to mandatory legislated standards and can be based on selfassessment or benchmarking. Accordingly, the countries in which the best practices to be taken into consideration are selected as per the dependency of the particular countries on the Heritage within the Tourism industry as mentioned below:

\begin{tabular}{|c|c|}
\hline $\begin{array}{l}\text { Country/ } \\
\text { Region/ } \\
\text { Organiza } \\
\text { tion }\end{array}$ & Best Practices Followed \\
\hline East Asia & $\begin{array}{l}\text { The digital reproduction of cultural heritage via "mass } \\
\text { photogrammetry", by providing approaches to digitize objects from } \\
\text { cultural heritage collections housed in museums or private spaces } \\
\text { using devices and photogrammetry techniques accessible to the public. }\end{array}$ \\
\hline $\begin{array}{l}\text { Europa } \\
\text { Nostra }\end{array}$ & $\begin{array}{l}\text { Launching a platform called Digital Agora, which aims at sharing and } \\
\text { promoting best practices related to culture and cultural heritage from } \\
\text { across the world, but in a digital form. The idea by Europa Nostra is } \\
\text { that through Digital Agora, citizens, heritage organizations, and } \\
\text { stakeholders are encouraged to connect, interact and learn from each } \\
\text { other, in this difficult time of the COVID-19 pandemic. }\end{array}$ \\
\hline Italy & $\begin{array}{l}\text { Incorporation of the } 4 \mathrm{P} \text { model, public-private-people-partnership for } \\
\text { heritage management. Eg: the Distretti Culturali (Cultural Districts) } \\
\text { project and the Attiv Aree (“Areactivation") program. } \\
\text { Museum experiences are being supported by digital technologies in } \\
\text { Campania region. }\end{array}$ \\
\hline $\begin{array}{l}\text { Angkor, } \\
\text { Cambodi } \\
\text { a }\end{array}$ & $\begin{array}{l}\text { On-site ticket sales are replaced by online sales, and physical tickets } \\
\text { must be replaced by electronic tickets. Visitors must sign a declaration } \\
\text { of responsibility stating that they meet the hygiene and health } \\
\text { requirements. They must have their temperature taken and watch for } \\
\text { other symptoms related to the virus. In case of symptoms, they must } \\
\text { call the helpline number provided for such purposes and follow the }\end{array}$ \\
\hline
\end{tabular}




\begin{tabular}{|c|c|}
\hline & $\begin{array}{l}\text { advice given. Furthermore, information must be provided in an } \\
\text { electronic form. }\end{array}$ \\
\hline USA & $\begin{array}{l}\text { Increasing social media engagement during this time. Continuing } \\
\text { digital content campaigns such as videos, blogs, partnerships, and paid } \\
\text { educational content. }\end{array}$ \\
\hline Japan & $\begin{array}{l}\text { The National Theatre has begun an attempt to release the video of the } \\
\text { Kabuki performance held in March } 2020 \text { for free on YouTube. }\end{array}$ \\
\hline Spain & $\begin{array}{l}\text { The widespread use of virtual spaces and social networks that the } \\
\text { online activity enables communities to share content through virtual } \\
\text { networks and museums, and the ability of users to develop, control, } \\
\text { and continuously update the content of websites. Ex: Prometheus fire } \\
\text { festival virtual museum }\end{array}$ \\
\hline China & $\begin{array}{l}\text { Limiting the number of tourists that can visit on a day and the arrivals } \\
\text { been planned as per the prior online bookings. Ex: Great wall }\end{array}$ \\
\hline Georgia & $\begin{array}{l}\text { Signing MOUs among the ministry of Education, science, culture, and } \\
\text { sports and the local authorities in the means of promoting cultural } \\
\text { routes. }\end{array}$ \\
\hline
\end{tabular}

Table 2: Best Practices followed

\section{Conclusions and Recommendations}

\section{Conclusion}

Heritage management has faced numerous difficulties time by time. Though, there are no $100 \%$ accurate solutions or techniques to face pandemics like Covid 19, safety measures and good hygiene practices may support face it and prevent the spreading. The heritage managers have to have a proper understanding and knowledge about the pandemic, heritage sites and also the visitors. Proper usage of guidelines and good practices of the heritage manager; supports the survival of the 
site and establishes sustainable practices for the long run with the Covid 19. The recommendations are made focusing on recovering and solving the main issues that can be identified in the heritage sites. These solutions are appropriate to meet the good results in a short period of time. Sustainable solutions for the long run will be discussed under the best practices.

1. The social distance should be followed with the health department guidelines

2. Empower staff with powers to abolish visitors who do not support the safety measures

3. Self-guiding and online guiding has to be promoted to avoid unwanted gathering inside the site

4. Online marketing and online ticketing services have to be introduced

5. Preparation of a timetable for visitation management

6. Promote destination visitation than site visitation - Design the plan for the long run

The recommended actions are as follows.

1. Increase ventilation chances inside the site

2. Avoid Air Conditioners and get natural air as much as possible

3. Locate sanitisers and handwashing facilities at the entrance, inside the site, and exits

4. Locate disinfection cubicles for staff and visitors

5. Reserve a room for emergency use

6. Online ticket reservation

7. Replace physical ticket checking with online check-in

8. Avoid contamination of virus through objects by prohibiting touching

9. Introduce virtual reality to manage visitors

10. Promote main heritage sites bundling with the lesser-known heritage sites in the vicinity

11. Enhance the online presence

12. Establishing a proper plan to limit the number of arrivals per day in order to minimize the congestion 


\section{References}

Alazaizeh, M., 2014. Sustainable Heritage Tourism: A Tourist-oriented Approach for Managing Petra Archaeological Park, (Unpublished Ph.D. thesis). Jordan: Clemson University.

Alvarez-Sousa, A. and PanizaPrados, J.L., 2020. Visitor management in world heritage destinations before and after Covid-19, Angkor. Sustainability, 12(23), p.9929.

Boniotti, C., 2021. The public-private-people partnership (P4) for cultural heritage management purposes. Journal of Cultural Heritage Management and Sustainable Development.

Buckley, Ralf. 2014. "Encyclopedia of Tourism.” Encyclopedia of Tourism (January 2014). doi: 10.1007/978-3-319-01669-6.

Ch'ng, E., Cai, S., Zhang, T.E. and Leow, F.T., 2019. Crowdsourcing 3D cultural heritage: best practice for mass photogrammetry. Journal of Cultural Heritage Management and Sustainable Development.

Gunasekara , I., 2019, Tourist Satisfaction towards Archaeological Heritage Sites in Sri Lanka with Special Reference to World Heritage Site Galle Dutch Fort, Journal of Human and Heritage: An Archaeological Spectrum of Asiatic Countries, New Bharatiya Book Corporation, New Delhi, Vol-1,pg.351-354.

Gunawardhane, P., 2008, Archaeological Heritage Management, Samanthi Publishers, JaEla, Sri Lanka.

Hua, Sun. 2010. "World Heritage Classification and Related Issues - A Case Study of the 'Convention Concerning the Protection of the World Cultural and Natural Heritage."' Procedia - Social and Behavioral Sciences 2(5):6954-61. doi: 10.1016/j.sbspro.2010.05.048.

Iguman, S., 2020. If visitors won't go to Heritage, Heritage must go to visitors. Digitisation of Heritage in time of Corona. Tourism facing a pandemic: from crisis to recovery.

Li, Yiping. 2000. "Ethnic Tourism a Canadian Experience." Annals of Tourism Research 27(1):115-31. doi: 10.1016/s0160-7383(99)00053-5.

Marmion, Maeve, Stephen Calver, and Keith Wilkes. 2010. “"Heritage? What Do You Mean by Heritage?"” Sharing Cultures 2009 (March 2015):575-83. 
Petronela, Tudorache. 2016. "The Importance of the Intangible Cultural Heritage in the Economy." Procedia Economics and Finance 39(November 2015):731-36. doi: $10.1016 / \mathrm{s} 2212-5671(16) 30271-4$.

Richards, Greg. 2013. “Cultural Tourism.” Routledge Handbook of Leisure Studies (January 2008):483-92. doi: 10.4324/9780203140505-55.

Richards, Greg. 2018. "Cultural Tourism: A Review of Recent Research and Trends." Journal of Hospitality and Tourism Management 36(October):12-21. doi: 10.1016/j.jhtm.2018.03.005.

Roigé, X., Arrieta-Urtizberea, I. and Seguí, J., 2021. The Sustainability of Intangible Heritage in the COVID-19 Era-Resilience, Reinvention, and Challenges in Spain. Sustainability, 13(11), p.5796

Ryder, B., Zhang, T. and Hua, N., 2021. The Social Media "Magic": Virtually Engaging Visitors during COVID-19 Temporary Closures. Administrative Sciences, 11(2), p.53.

Singer, Graciela Gestoso. 2012. "Intangible Heritage." Heritage, Memory \& Identity (09):314-17. doi: 10.4135/9781446250839.n31.

Thorell, Tomas Nilson \&. Kristina. 2018. Cultural Heritage and Preservation. Halmstad: Författarna och Halmstad University Press.

Varriale, L., Volpe, T. and Noviello, V., 2021. Enhancing Cultural Heritage at the Time of the COVID-19 Outbreak: An Overview of the ICT Strategies Adopted by Museums in the Campania Region of Italy. Tourism Destination Management in a Post-Pandemic Context.

Walker, Cameron. 2008. “Archaeological Tourism: Looking for Answers Along Mexico’S Maya Riviera.” NAPA Bulletin 23(1):60-76. doi: 10.1525/napa.2005.23.1.60.

https://ich.unesco.org/en/living-heritage-experience-and-covid-19-pandemic$\underline{01124}$ ?id=00073 $($ accessed on 31st August 2021) 